\title{
Genetic structure, reproductive biology and ecology of isolated populations of Asplenium csikii (Aspleniaceae, Pteridophyta)
}

\author{
JOHANNES C. VOGEL*†, FREDERICK J. RUMSEY†, STEPHEN J. RUSSELL $\dagger$, \\ CYMON J. COX†, JACQUELINE S. HOLMES $\uparrow$, WALTER BUJNOCH $\$$, CHRISTOPH \\ STARK§, JOHN A. BARRETT \& MARY GIBBY† \\ $\dagger$ Plant Molecular Biology Laboratory, Department of Botany, The Natural History Museum, Cromwell Road, London \\ SW7 5BD, U.K., $₫$ Neuwiese 13, D-54269 Trier, Germany, §Lindenstrasse 18, D-67346 Speyer, Germany and \\ - Department of Genetics, University of Cambridge, Downing Street, Cambridge CB2 3EH, U.K.
}

\begin{abstract}
The potential for environmental heterogeneity to generate spatial structuring of genotypes in seedplant populations that occupy patchy habitats has been demonstrated by several studies, but little is known about the population structure of pteridophytes occupying patchy environments. In this study we have examined the genetic structure of isolated populations of the rock fern Asplenium csikii, an ecological specialist, growing almost exclusively on perpendicular walls of natural rock outcrops. All genetic variation observed in this taxon was partitioned between localities; no allozyme variation was found within a site and each site was colonized by a single multilocus phenotype (MLP). In total, five different MLPs were recorded from the nine localities, with two MLPs present at more than one site. Previous examination of population structure and genetic diversity in another rock fern, $A$. rutamuraria, showed that the genetic diversity increases through multiple colonization over time. However, we cannot find any such correlation for A. csikii. All populations are genetically uniform, despite the probably considerable age of the populations and sites. Earlier studies concluded that the ample production of wind-borne propagules would lead to multiple colonization of sites and that reproductive features, such as single-spore colonization and subsequent intragametophytic selfing, would lead to very little genetic structuring of fern populations. In contrast to this prediction, it appears that ecological specialization and the scarcity of the narrowly defined niche contribute strongly to the pronounced partitioning of genetic variability observed in populations of $A$. csikii.
\end{abstract}

Keywords: allozymes, Asplenium csikii, breeding systems, colonization, isolated populations, polyploidy.

\section{Introduction}

The genetic structure of plant populations is determined by factors such as mutation, migration, selection, drift and breeding systems that operate within the historical and biological context of the species, but may also be influenced by stochastic effects (Loveless \& Hamrick, 1984; Levin, 1988). Most studies consider the genetic structure of seed-plant populations but little is known about population structure in pteridophytes. Here we investigate the factors that may be important in determining the genetic structure of isolated populations of the rock fern Asplenium csikii Kümmerle \& Andras. in western Germany, Luxembourg and northern France.

*Correspondence. E-mail: j.vogel@nhm.ac.uk
Many rock ferns have highly fragmented populations, especially in areas of Europe outside the major mountain chains. In most of central Europe natural rock outcrops are scarce and scattered and are either of volcanic origin or associated with river valleys and other erosion processes. Rock outcrops are extreme environments, with edaphic factors such as the low availability of water and nutrients, and exposure to wind and sun. Therefore, they can often be colonized only by specially adapted plants.

Ferns disperse via wind-borne spores and individual plants can produce several million per year. These haploid spores are very small, $\approx 40 \mu \mathrm{m}$, and are therefore capable of long-range dispersal (Van Zanten, 1978) which can aid the exchange of genetic variation despite the fragmentation of populations. On germination the haploid spores grow into haploid prothalli which can 
develop into hermaphroditic gametophytes (Schneller, 1988). A sporophyte can then be produced via intragametophytic selfing. Therefore, a single spore can colonize a new, previously unexploited habitat via long- or short-range dispersal and subsequently establish a sexually reproducing colony (Crist \& Farrar, 1983). It has been postulated in the past that very little genetic structuring exists in fern populations (Klekowski, 1972; Soltis \& Soltis, 1989). Reports of high interpopulational gene-flow based on allozyme studies supported this hypothesis, especially in outbreeding ferns (Soltis \& Soltis, 1987, 1990; Hooper \& Haufler, 1997). Most of these studies concerned woodland ferns but several investigations on rock ferns are available for comparison, e.g. Cheilanthes gracillima D.C. Eaton in western United States (Soltis et al., 1989) and A. septentrionale (Holderegger \& Schneller, 1994) and A. ruta-muraria L., both from Switzerland (Schneller \& Holderegger, 1996).

Asplenium csikii grows directly on perpendicular calcareous rocks, in crevices, under overhangs, or more rarely on man-made walls. In these habitats it appears to be sheltered from direct rain and is apparently intolerant of water retained in the crown (pers. obs. from fieldwork and garden cultivation). Asplenium csikii is characterized by a unique growth habit with its fronds pressed against the rock, lying flat like a starfish (Fig. 1); this is presumably an adaptation to reduce transpiration. It grows directly in the rock, with very little or no soil to retain water and thus depends on porous rock as a water reservoir. At such sites, A. csikii is often the sole vascular plant. It normally grows on limestone, seldom in calcareous sandstone and very rarely in mortar in man-made walls. It prefers well-shaded sites, e.g. northfacing walls or rock outcrops in woodlands, with a relatively high humidity. In Europe $A$. csikii is widespread but scattered. The centres of its distribution are the limestone massifs in southern France (Boudrie, 1988; Labatut et al., 1990; Prelli \& Boudrie, 1992), the Schwäbische Alb and Fränkische Alb in southern Germany (Schulze in Lovis \& Reichstein, 1985; pers. obs.), montane limestone areas (400-1000 m) in Switzerland and Austria, and the mountains in south-eastern Europe (Reichstein, 1984). Asplenium csikii is a sexual tetraploid taxon within the $A$. trichomanes L. complex, it is synonymous with $A$. trichomanes ssp. pachyrachis (Christ) Lovis \& Reichst. (Lovis \& Reichstein, 1985) and was probably derived from the calcicole diploid A. trichomanes s.l. (Vogel, unpubl.). Several taxa within the $A$. trichomanes complex are currently recognized in Europe, but our knowledge of their distribution is still unsatisfactory. However, very detailed distribution data for A. csikii exist for parts of western Germany (Rheinland-Pfalz), Luxembourg and adjacent northeastern France (Schulze, 1990; Bujnoch, 1993; Lang \&

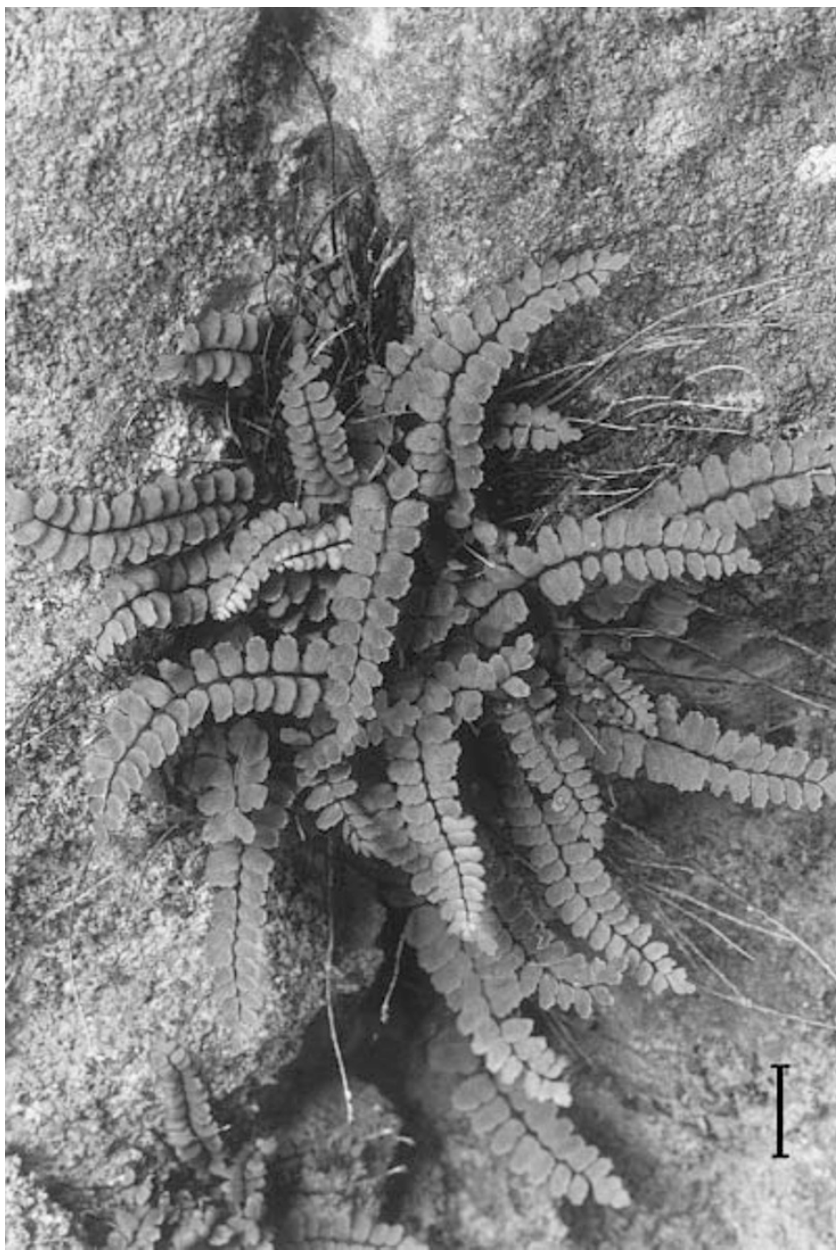

Fig. 1 The small fern Asplenium csikii is an ecological specialist. It grows directly in rocks, with very little or no soil to retain water and thus depends on porous rock as a water reservoir. At such sites, A. csikii is often the sole vascular plant. Scale bar represents $1 \mathrm{~cm}$. Photo: Vogel.

Wolff, 1993; Haffner \& Wachter, 1994; Parent et al., 1996; Parent, 1997). In this area, covering some $25000 \mathrm{~km}^{2}, A$. csikii is confined to $\approx 10-15$ sites mainly on calcareous sandstone outcrops. This situation offered us the opportunity to study nearly all populations in order to investigate the distribution of genetic variation of these naturally highly fragmented populations of this rare and ecologically specialized plant.

\section{Materials and methods}

\section{Sampling}

Material for allozyme electrophoresis was obtained by the collection of single fronds of Asplenium plants in the wild. Vouchers from populations investigated have been deposited at the Natural History Museum, London (BM). 
Table 1 Locality, substrate, population structure, sample size and multilocus phenotype of the isolated populations of Asplenium csikii in western Germany and adjacent Luxembourg and France, roughly in north to south order. Site numbers as in Fig. 3

\begin{tabular}{|c|c|c|c|c|}
\hline Locality & Substrate & Population structure & $\begin{array}{l}\text { Sample } \\
\text { size }\end{array}$ & $\begin{array}{l}\text { Multilocus } \\
\text { phenotype }\end{array}$ \\
\hline 1. Gerolstein, Munterley & Natural dolomitic limestone & 2 populations & 60 & MLP-3 \\
\hline 2. Gerolstein, Auberg & Natural dolomitic limestone & 1 population & 30 & MLP-1 \\
\hline 3. Bitburg & Natural sandstone rocks & 1 population & 30 & MLP-1 \\
\hline 4. Irrel & $\begin{array}{l}\text { Natural limestone } \\
\text { rocks/boulders }\end{array}$ & 2 populations, $\approx 300 \mathrm{~m}$ apart & 76 & MLP-1 \\
\hline 5. Müllerthal & Natural sandstone rocks & 1 population & 30 & MLP-1 \\
\hline 6. Neuscharfeneck, ruin & Natural sandstone rocks, walls & Several (sub) populations & 33 & MLP-4 \\
\hline 7. Dahn, ruin Altdahn & Natural sandstone rocks, walls & $\begin{array}{l}\text { Several (sub) populations } \\
\text { from all around the outcrop }\end{array}$ & 58 & MLP-2 \\
\hline 8. Lemberg, ruin & Natural sandstone rocks, walls & $\begin{array}{l}\text { Several (sub) populations from } \\
\text { all around the outcrop }\end{array}$ & 87 & MLP-2 \\
\hline 9. Rocher du Dabo & Natural sandstone rocks & Several (sub) populations & 28 & MLP-5 \\
\hline
\end{tabular}

The distribution of sites, the underlying rock and the sample sizes for each locality are given in Table 1. If the locality consisted of a uniform rock face, up to 30 individuals were collected. Where several sites at a locality were colonized, as many populations as possible were collected. For each population, the number of plants, the area covered and exposure and position in relation to other populations were recorded in the field, and as many plants and populations as possible were sampled at each site. In total 432 plants were sampled from the nine major sites for A. csikii.

\section{Electrophoresis}

Allozyme electrophoresis was carried out on Asplenium plants using established methods (Soltis et al., 1983; Haufler, 1985; Wendel \& Weeden, 1989). The following enzyme systems were informative and could be analysed for locus and allelic variation: aconitase $(\mathrm{ACN}, \mathrm{EC}$ 4.2.1.3), aldolase (ALD, 4.1.2.13), aspartate aminotransferase (AAT, 2.6.1.1), diaphorase (DIA, 1.6.99.-), glutamate dehydrogenase (GDH, 1.4.1.2), hexokinase (HEX, 2.7.1.1), isocitrate dehydrogenase (IDH, 1.1.1.42), leucine aminopeptidase (LAP, 3.4.11.1), malate dehydrogenase (MDH, 1.1.1.37), phosphoglucoisomerase (PGI, 5.3.1.9), phosphoglucomutase (PGM, 5.4.2.2), 6-phosphogluconate dehydrogenase (6-PGD, 1.1.1.44), shikimate dehydrogenase ( $\mathrm{SkDH}, 1.1 .1 .25)$ and triose-phosphate isomerase (TPI, 5.3.1.1). Enzyme systems were resolved on a combination of gel/buffer systems using $12.8 \%$ starch gels. The enzyme systems IDH, MDH, 6-PGD, HEX, SkDH, ACN, GDH were resolved with morpholine-citrate buffers over the $\mathrm{pH}$ range of 6.4-7.4 (Wendel \& Weeden, 1989), whereas LAP, PGI, PGM, TPI, AAT, ALD, DIA were resolved on a modified System 7 (Soltis et al., 1983) over the $\mathrm{pH}$ range of 8.3-9.3. Band homologies were determined by running samples side-by-side on the same gel. Allelic variants within loci were distinguished from products of different loci by assuming that the enzymes in Asplenium conform to established models of organelle compartmentalization (Gastony \& Darrow, 1983; Weeden \& Wendel, 1989). The most anodally migrating locus was labelled ' 1 ', and alleles were designated alphabetically. The interpretation of the (sometimes) complex banding patterns was aided by comparison with data from a comprehensive survey of the genetic diversity in ancestral diploid $A$. trichomanes (Vogel et al. unpubl.). The allele mobilities are included in Fig. 2 to allow crosscomparison with other studies.

\section{Breeding experiments}

Experiments were carried out to determine whether sporophytes of $A$. csikii can be raised from individual gametophytes via intragametophytic selfing. In one approach fronds of two plants from Irrel (Locality 4) were collected. Then individual sporangia were isolated from the sori. Under the microscope an individual spore from a sporangium was collected and transferred onto sterilized soil in a small, sealed, glass tube. This was repeated 10 times. Each spore germinated into a single gametophyte and after several months the production of a sporophyte was observed in all 10 tubes.

The other approach used the method described by Lovis (1968). Samples of spores of A. csikii from Germany (ex spore exchange of the British Pteridological Society, collected in 11/88 by Stefan Jeßen, Chemnitz) were sown directly on sterilized soil for hybridization experiments (for further details see Vogel 


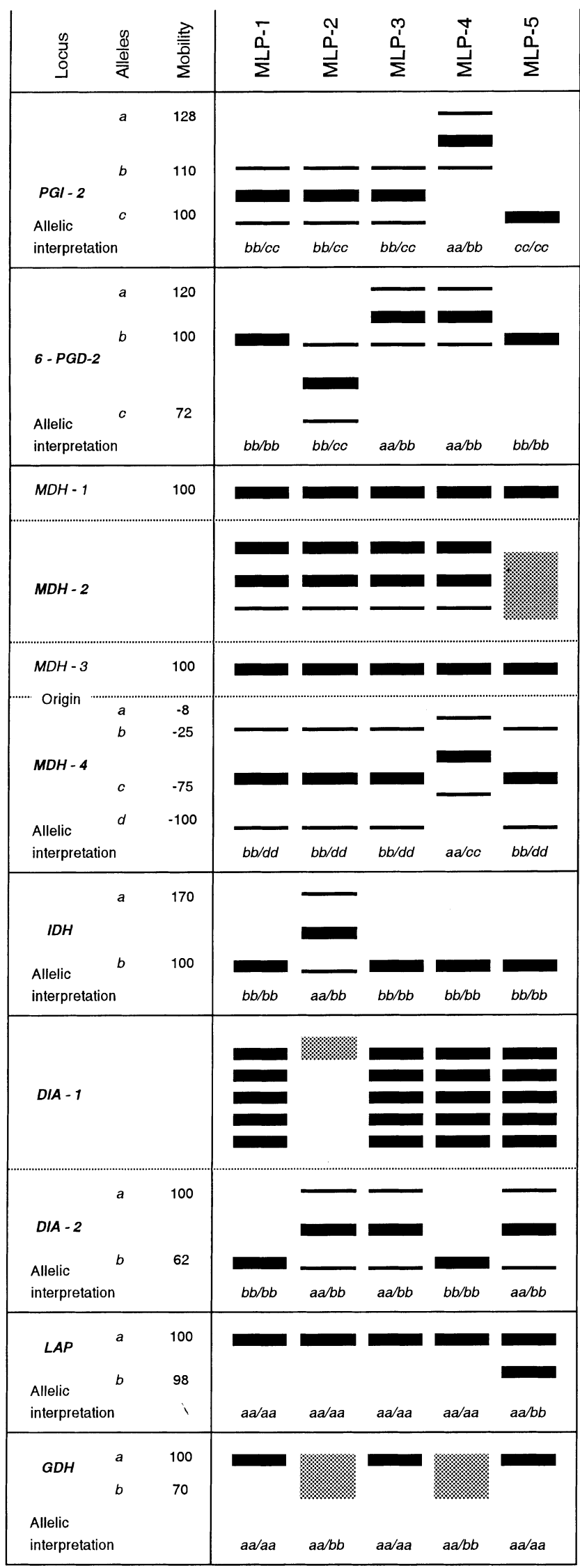

Fig. 2 Variable loci, allelic interpretation and the multilocus phenotypes (MLP-1-5) in Asplenium csikii in western Germany and adjacent areas. Asplenium csikii is a sexual tetraploid taxon and the interpretation of the (sometimes) complex banding patterns was aided by a comprehensive survey of the genetic diversity in ancestral diploid A. trichomanes. The most anodally migrating locus was labelled ' 1 ', and alleles were designated alphabetically. Allele mobility is included to allow cross-comparison with other studies. The migration of $\mathrm{MDH}-4$ is cathodal.

et al., 1998a). A few weeks after germination over 100 small gametophytes were isolated from the initial dense sowings. These gametophytes were placed into larger pots, thereby preventing intergametophytic fertilization, and this also allowed gametophytes to become quite large. Some of these large gametophytes were used in hybridization experiments (Vogel et al., 1998a). However, some $80 \%$ of these isolated gametophytes were maintained in culture, and over the next 12 months the development of sporophytes, presumably by intragametophytic selfing, was observed on all gametophytes. The two populations studied in these experiments (from Irrel and from Stefan Jeßen) are genetically distinct.

\section{Results}

Twenty-three loci in 14 enzyme systems were stained and analysed. Nine loci - PGI-2, 6-PGD-2, $M D H-2$, $M D H-4, I D H, D I A-1, D I A-2, L A P$ and $G D H$ - proved to be variable in the populations of $A$. csikii studied from western Germany and adjacent areas in Luxembourg and France. The variable loci and the allelic interpretation of this variation are given in Fig. 2.

All genetic variation observed was partitioned between localities (Fig. 3, Table 1). No allozyme variation was found within a site and each site was occupied by a single multilocus phenotype (MLP). In total, five different MLPs were recorded from the nine localities (Fig. 3). Two MLPs, MLP-1 and MLP-2, were present at more than one site, with MLP-1 being the most widespread type, colonizing four localities from Luxembourg northeastwards towards Gerolstein-Auberg, a distance of some $60 \mathrm{~km}$. MLP-2 was restricted to two sites in the Wasgau, Dahn and Lemberg, near the German-French border. These two sites are approximately $12 \mathrm{~km}$ apart, and some $20-30 \mathrm{~km}$ south-east of Neuscharfeneck, the locality with MLP-4. Rocher du Dabo is the most southern site studied and is $60-75 \mathrm{~km}$ away from the localities with MLP-2 and MLP-4; MLP-5 was found uniquely on this 'free-standing' mountain. The locality Gerolstein-Munterley, only about $1 \mathrm{~km}$ away from Gerolstein-Auberg, is colonized by the unique MLP-3. 


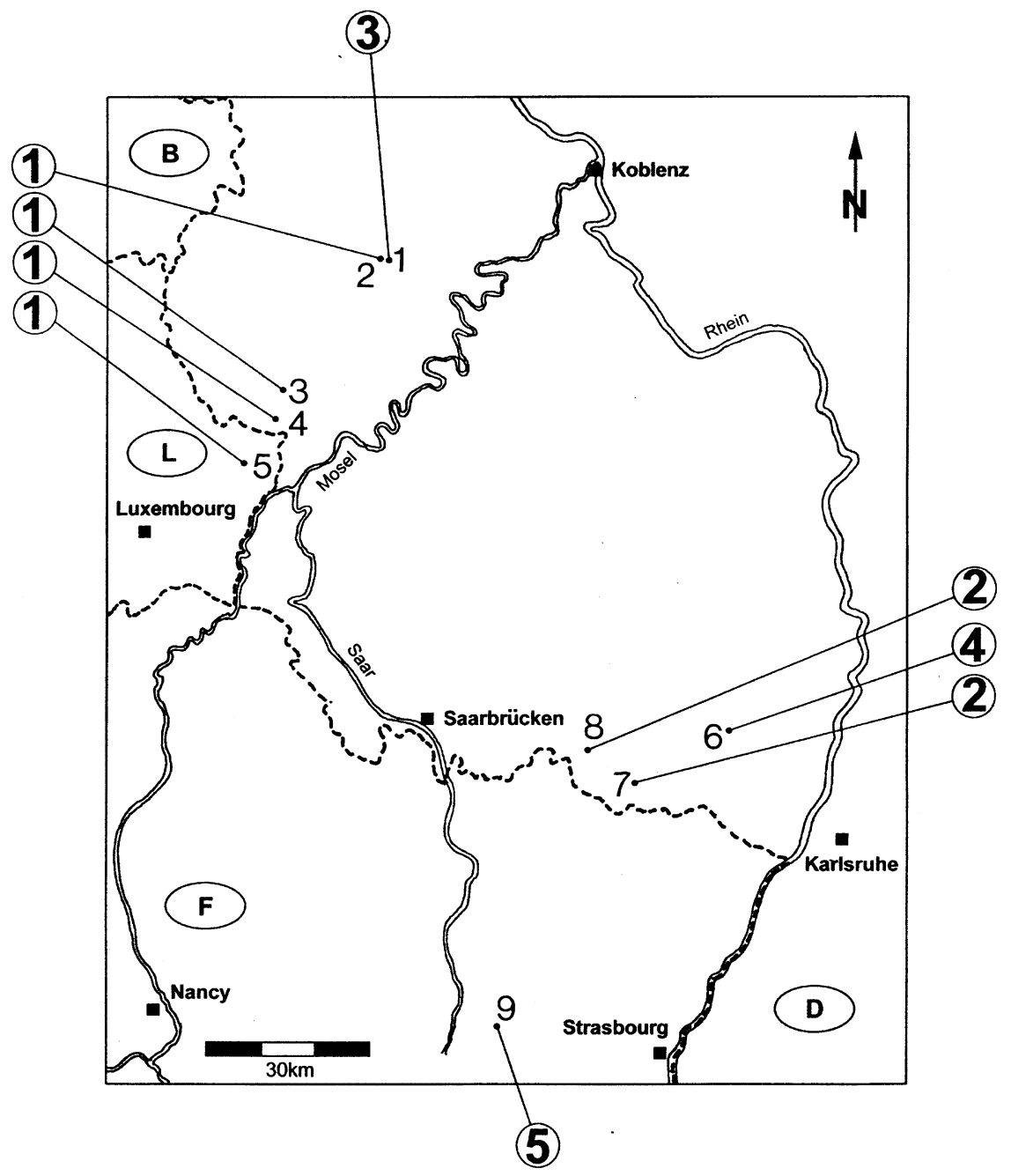

Fig. 3 The distribution of genetic diversity in the rock fern Asplenium csikii in western Germany, adjacent Luxembourg and France. All sites are colonized by a single multilocus phenotype, indicated by numbers in circles. Multilocus phenotype 1 (MLP-1) was found at four sites in the west, MLP-2 was found at two sites in the south and MLP-3-MLP-5 were unique. Site numbers are as in Table 1.
This distribution of genetic diversity in A. csikii in western Germany and adjacent areas indicates that the proximity of sites has some influence on the colonization. Local colonization has most certainly contributed to the distribution of two MLPs: the two sites for MLP-2 are closest to each other and MLP-1 seems to have colonized all suitable sites over a $60-\mathrm{km}$ range ('stepping-stone' dynamics). However, the other sites have been colonized by unique multilocus phenotypes, probably via long-range spore dispersal, and such colonies seem not to have been influenced by nearby local sources.

In the breeding experiments by Bujnoch each spore germinated into a single gametophyte that subsequently produced sporophytic plants. In London, isolated gametophytes, which had not been artificially fertilized, developed sporophytes during the subsequent year. We conclude from these breeding experiments that sporophytes of $A$. csikii can grow following intragametophytic selfing. Therefore, this fern can potentially colonize a site with a single spore. However, we cannot determine which breeding system prevails in $A$. csikii populations at these localities. Because each site is occupied by a single multilocus phenotype, any distinction between outbreeding, intergametophytic selfing and intragametophytic selfing becomes semantic.

\section{Discussion}

The potential for environmental heterogeneity to generate spatial structuring of genotypes in plant populations that occupy pronouncedly patchy habitats has been demonstrated by several studies (Heywood, 1991; see references therein). However, little is known about the population structure of pteridophytes that occupy patchy environments. From evidence collected by several authors on the distribution patterns of tropical ferns, especially on oceanic islands, it has been suggested that, owing to high spore production, potentially high dispersibility and long spore viability, genetic structuring 
among fern populations might not be expected (Tryon, 1970, 1986; Klekowski, 1972). Reports of high interpopulational gene-flow based on allozyme studies supported this hypothesis, especially in outbreeding ferns (Soltis \& Soltis, 1987, 1990; Hooper \& Haufler, 1997). Soltis et al. (1989) found marked genetic structuring between and within populations of the rock fern Cheilanthes gracillima D.C. Eaton, a sexual species from the western United States (Windham \& Rabe, 1993). They investigated several (sub) populations from five localities for nine allozyme loci and based their interpretation on Wright's $F$-statistics. Unfortunately, the ploidy of this fern has not been determined (Soltis et al., 1989; Windham \& Rabe, 1993). Knowledge of ploidy is critical for the allocation of genotypes to electrophoretic patterns and subsequent calculation of $F$-values. Watano (1988) reported high levels of genetic divergence between populations in tetraploid Pteris multifida Poir. and concluded that, in part, intragametophytic selfing was involved. However, a careful reexamination of the same populations by Murakami et al. (1997) revealed that the fern was predominately outbreeding and that Watano's study had not taken population substructuring into account, leading to a misinterpretation of the breeding system (Wahlund effect). Three different reviews by Soltis \& Soltis (1987, $1989,1990)$ on essentially a single data set, reported $F_{\text {ST }}$ values for pteridophytes between 0.024 and 0.235 , and they concluded that homosporous pteridophytes maintain most of their genetic variation within, rather than between, populations. Our results are in stark contrast to these findings, with all genetic diversity partitioned between populations.

Allozyme electrophoresis has proved to be a useful tool not only to investigate the biosystematic relationships between taxa in the highly reticulate Asplenium trichomanes complex, but also to study the partitioning of genetic variation within taxa (Vogel et al., 1998b, 1999; unpubl. data). Studies on both diploid and polyploid European rock ferns have revealed structuring within and between populations (Vogel et al. unpubl. data). To avoid the possibly confounding effects of population structure and breeding system in A. csikii, great care was taken in the design of the sampling procedure at each locality. For each subpopulation, the number of plants, the area covered, exposure and position in relation to other populations were recorded in the field and as many plants and subpopulations as possible were sampled at each locality. Most genetic studies on homosporous ferns have investigated eight to 12 allozyme loci (Soltis \& Soltis, 1989), but we have investigated 23 allozyme loci for A. csikii. Despite this effort, in both sampling and in carrying out the analysis, no genetic diversity within localities was revealed in
A. csikii. All genetic diversity was distributed between sites, despite their, often close, proximity, e.g. less than $1 \mathrm{~km}$ between Gerolstein-Auberg and GerolsteinMunterley.

The breeding experiments reported above suggest that A. csikii can form $\mathrm{F}_{1}$ sporophytes from isolated spores via intragametophytic selfing. Such $F_{1}$ plants are completely homozygous with no segregation in the $F_{2}$ generation, and therefore a colony developing in this way will be genetically uniform, in the absence of further immigrant spores. Slatkin (1987) pointed out that the possibility and frequency of immigration depends on the distance from the next source of immigrants. Despite the fact that natural rock outcrops are scattered in central Europe, one would not expect such a strong partitioning of genetic variation and the apparent absence of multiple colonization in rock fern populations. Holderegger \& Schneller (1994) showed that small and isolated populations of $A$. septentrionale were variable and concluded that this variation had originated from multiple colonization events. Schneller \& Holderegger (1996) examined 40 populations of the tetraploid WallRue, A. ruta-muraria L., in and around Zürich in Switzerland. They discovered that populations on recently established walls (younger than 80 years) were usually void of genetic variation, whereas populations on old walls and natural sites were genetically variable. Schneller \& Holderegger (1996) concluded that multiple colonization had taken place and they were able to establish a link between the age of the site and the likelihood of repeated colonization for A. ruta-muraria (see also Giles \& Goudet, 1997). In the area covered by this study, A. csikii grows on natural rock faces. These rock faces have been available for colonization for perhaps as long as 10000 years. Castles have been built on the summits of the more spectacular rock outcrops, although many are now in ruins. On these mountains A. csikii is most abundant on natural rock faces but has subsequently colonized weathered cracks containing mortar in the ruins. Asplenium csikii is a calcicole taxon, and the sandstone in the area is lime-rich with a high water-retaining/storage capacity (Lüpnitz \& Steger, 1989 ) and thus provides an adequate substrate. Furthermore, A. csikii, unlike A. ruta-muraria, has not been reported from any other man-made structure or wall in this area. This might result from the different chemical compositions of some mortars, or from chemical and physical changes taking place during weathering of the mortar. In contrast we find that all populations are genetically uniform, despite the probably considerable age of the populations and sites.

Polyploid ferns have been reported to favour intragametophytic selfing (Masuyama \& Watano, 1990). Suter \& Schneller (1986) demonstrated that the 
tetraploid $A$. ruta-muraria is capable of intragametophytic selfing to produce a sporophyte plant, and the experiments carried out in this study demonstrate the same ability for $A$. csikii. The differences in the population structures observed between these two taxa cannot therefore be attributed to differences in breeding system, during initial colonization of a site with a single spore. However, the most striking difference between the two taxa seems to lie in their relative ecological amplitudes and abilities to exploit new man-made habitats. Tetraploid A. ruta-muraria is one of the most widespread and common ferns in Europe (Jalas \& Suominen, 1972; Reichstein, 1984). The natural habitat of A. ruta-muraria is calcareous rock faces, but it has been able to expand its range by colonizing mortar in man-made walls. The wide ecological amplitude and the relative abundance of $A$. ruta-muraria at many sites in central Europe might increase the probability of multiple colonization. In contrast, A. csikii is more or less confined to a much rarer and very special niche in natural rock faces, perpendicular walls or overhangs that prevent direct contact with water. Despite the fact that $A$. csikii seems to be well adapted for the colonization of new sites via single spores and subsequent intragametophytic selfing, safe (micro) sites for gametophyte development, i.e. moist cracks, may be extremely difficult to reach in the first instance. At its known sites, A. csikii appears to be a successful plant and fresh recruitment within colonies was always observed at the study sites. Asplenium csikii plants are often covered in spiders' webs and one can assume that ample spore production and dispersal by small animals, birds, insects or spiders is responsible for successful local colonization within a site. However, such vectors may not be mobile enough to guarantee dispersal between suitable sites even over distances of less than $1 \mathrm{~km}$.

For the area covered in this study it appears that the partitioning of genetic variation in $A$. csikii, and some ecological features, are shared with the gametophytes of the filmy-fern Trichomanes speciosum Willd. Both taxa depend on shelter and rock-borne water/humidity supplied by the sandstone, and are often the sole plants at their specialized microniches. At some localities the two taxa grow very closely together on the same outcrop. Rumsey et al. (1998a) investigated the genetic diversity in isolated gametophyte colonies of $T$. speciosum from the same area in western Germany. Trichomanes speciosum is a Macaronesian-European endemic and the sporophyte is restricted to areas of hyperoceanic climate, but the gametophytes have recently been found outside the range of the sporophyte in continental Europe (Vogel et al., 1993; Rasbach et al., 1994; Rumsey et al., 1998b, for summary of literature). The two phases of the life cycle in $T$. speciosum can have different ecological requirements and niches. In central Europe the gametophytes dwell in dark, deep sandstone recesses and depend on the ameliorated microclimate in such sites to survive an adverse macroclimate that currently prevents the occurrence of sporophytes. The gametophytes reproduce asexually via gemmae that can contribute to local distribution, e.g. by small invertebrates. However, these gemmae are unlikely to survive longrange transport because of irreversible desiccation (Rumsey \& Sheffield, 1996). A local clustering of genetic variation was observed in $T$. speciosum gametophyte populations from the same area and genetic variability was partitioned mainly between populations (Rumsey et al., 1998a).

Superficially, the partitioning of genetic variation appears to be similar for T. speciosum and A. csikii. However, the causes that have led to this distribution are different. It can be speculated that in the past, e.g. during the Atlantic hypsithermal, sporophytes of $T$. speciosum might have had a wide distribution in the area and a similarly wide ecological niche as observed currently only on some Macaronesian islands, leading to a flourishing of diversity in local areas. The partitioning of genetic diversity in the surviving gametophyte generation is therefore an artefact of historical processes. For $T$. speciosum, factors such as historical climatic fluctuations, a split in the life cycle and differences in the ecological requirements of the two phases of this life cycle, allowing only one generation to survive, have been responsible for the observed patterns of genetic diversity. None of these factors is likely to have affected the genetic diversity in $A$. csikii, because the life cycle is complete and both sporophyte and gametophyte share the same, albeit narrow, niche. In A. csikii the most critical factor appears to be the precise niche requirement. Suitable niches are also unlikely to have been more abundant under different macroclimatic regimes. The sandstone rock-houses, overhangs and walls supporting populations of $A$. csikii appear to be very stable environments, but only enable specialists to colonize and survive. Such habitats have always been very scattered, and thus perhaps have a reduced probability of multiple colonization.

Previous studies have concluded that ample production of wind-borne spores and multiple colonization as well as the reproductive features of ferns, such as singlespore colonization and subsequent intragametophytic selfing, would lead to very little genetic structuring of fern populations. In contrast with this prediction, it appears that ecological specialization and scarcity of the well-defined niche contribute strongly to the pronounced partitioning of genetic variability observed in populations of $A$. csikii in western Germany and adjacent areas. 


\section{Acknowledgements}

We wish to thank the Natural Environmental Research Council (GR3/09451) and the Museum Research Fund for supporting this work. We would also like to thank the people who have provided information, assistance and hospitality, especially Angelika Stark, Claude Jérôme, U. Kottke, Lars Schmitt, Harry Taylor and Günther Zenner.

\section{References}

BOUDRIE, M. 1988. Asplenium trichomanes L. subsp. pachyrachis (Christ) Lovis and Reichstein et Asplenium trichomanes L. nothosubsp. staufferi Lovis and Reichstein (A. trichomanes subsp. pachyrachis $\times$ A. trichomanes subsp. quadrivalens) sur les marges occidentales calcaires du Massif Central (France). Bull. Soc. Bot. Centre-Ouest, 19, 35-38.

BujNOCH, w. 1993. Farnstandorte im Regierungsbezirk Trier, 9. Nachtrag. Dendrocopos, 20, 226-233.

CRIST, K. C. AND FARRAR, D. R. 1983. Genetic load and longdistance dispersal in Asplenium platyneuron. Can. J. Bot., 61, 1809-1814.

GASTONY, G. J. AND DARRow, D. C. 1983. Chloroplastic and cytosolic isozymes of the homosporous fern Athyrium filixfemina L. Am. J. Bot., 70, 1409-1415.

GILES, B. E. AND GOUDET, J. 1997. Genetic differentiation in Silene dioica metapopulations: estimation of spatio-temporal effects in a successional plant species. Am. Nat., 149, 507-526.

HAFFNER, P. AND WACHTER, H. 1994. Die Unterarten und Hybriden des Braunen Streifenfarns Asplenium trichomanes im Nordwestsaarland und in angrenzenden Gebieten. Delattinia, 21, 59-106.

HAUFLER, C. H. 1985. Enzyme variability and modes of evolution in the fern genus Bommeria. Syst. Bot., 10, 92-104.

HEYwOod, J. S. 1991. Spatial analysis of genetic variation in plant populations. Ann. Rev. Ecol. Syst., 22, 335-355.

HOLDEREGGER, R. AND SCHNELLER, J. J. 1994. Are small isolated populations of Asplenium septentrionale variable? Biol. J. Linn. Soc., 51, 377-385.

HOOPER, E. A. AND HAUFLER, C. H. 1997. Genetic diversity and breeding system in a group of neotropical epiphytic ferns (Pleopeltis; Polypodiaceae). Am. J. Bot., 84, 1664-1674.

JALAS, J. AND SUOMINEN, J. (eds) 1972. Atlas Florae Europaeae, vol. 1, Pteridophyta. University of Helsinki Press, Helsinki.

KLEKOWSKI, E. J. 1972. Genetical features of ferns as contrasted to seed plants. Ann. Mo. Bot. Gard., 59, 138-151.

LABATUT, A., Boudrie, M. AND ENJELVIN, P. 1990. Asplenium trichomanes L. subsp. pachyrachis (Christ) Lovis et Reichstein dans le Puy-De-Dome (France). Le Monde des Plantes, 439, 25 .

LANG, W. AND WOlfF, P. (eds) 1993. Flora der Pfalz. Verlag der Pfälzischen Gesellschaft zur Förderung der Wissenschaften, Speyer.

LEVIN, D. A. 1988. Consequences of stochastic elements in plant migration. Am. Nat., 132, 643-651.
LOVELESS, M. D. AND HAMRICK, J. L. 1984. Ecological determinants of genetic structure in plant populations. Ann. Rev. Ecol. Syst, 15, 65-95.

LOVIS, J. D. 1968. Fern hybridists and fern hybridising II. Fern hybridising at the University of Leeds. Brit. Fern Gaz., 10, 13-20.

LOVIS, J. D. AND REICHSTEIN, T. 1985. Asplenium trichomanes subsp. pachyrachis (Aspleniaceae, Pteridophyta), and a note on the typification of $A$. trichomanes. Willdenowia, 15, 187-201.

LÜPNITZ, D. AND STEGER, T. 1989. Flora und Vegetation auf Buntsandsteinfelsen im südlichen Pfälzerwald. Mainzer Naturwiss. Archiv, 27, 155-194.

MASUYAMA, S. AND WATANO, Y. 1990. Trend for inbreeding in polyploid pteridophytes. Pl. Sp. Biol., 5, 13-17.

MURAKAMI, N., NISHIYAMA, T., SATOH, H. AND SUZUKI, T. 1997. Marked spatial genetic structure in three populations of a weedy fern, Pteris multifida Poir., and re-estimation of its selfing rate. Pl. Sp. Biol., 12, 97-106.

PARent, G. H. 1997. Atlas des Ptéridophytes des régions lorraines et vosgiennes, avec les territoires adjacents. Travaux Scientifiques du Musee national d'histoire naturelle de Luxembourg, 25, 1-307.

PARENT, G. H., JÉRÔME, C. AND THORN, R. 1996. Donnees nouvelles sur la repartition d'Asplenium trichomanes L. subsp. pachyrachis (Christ) Lovis and Reichstein (Aspleniaceae, Pteridophyta) en Belgique, au Grand-Duche de Luxembourg, en Allemagne et dans le nord-est de la France. Le Monde de Plantes, 457, 29-30.

PRELli, R. AND BOUDRIE, M. 1992. Atlas écologique des fougères et plantes alliées. Illustration et répartition des Ptéridophytes de France. Lechevalier, Paris.

RASBACH, H., RASBACH, K. AND JÉRÔME, C. 1994. Über das Vorkommen des Hautfarns Trichomanes speciosum (Hymenophyllaceae) in den Vogesen (Frankreich) und dem benachbarten Deutschland. Carolinea, 51 ('1993'), 51-52.

REICHSTEIN, T. 1984. Aspleniaceae. In: Kramer, K. U. (ed.) Illustrierte Flora von Mitteleuropa, 3rd edn., vol. I, part 1, pp. 211-275. Paul Parey, Hamburg.

RUMSEY, F. J. AND SHEFFIELD, E. 1996. Inter-generational ecological niche separation and the independent gametophyte' phenomenon. In: Camus, J. M., Gibby, M. and Johns, R. J. (eds) Pteridology in Perspective, pp. 563-570. Royal Botanic Gardens, Kew.

RUMSEY, F. J., VOGEL, J. C., RUSSELl, S. J., BARRETT, J. A. AND GIBBY, M. 1998a. Climate, colonization and celibacy: population structure in central European Trichomanes speciosum (Pteridophyta). Bot. Acta, 111, 481-489.

RUMSEY, F. J., JERMY, A. C. AND SHEFFIELD, E. 1998b. The independent gametophytic stage of Trichomanes speciosum Willd. (Hymenophyllaceae), the Killarney Fern and its distribution in the British Isles. Watsonia, 22, 1-19.

SCHNELLER, J. J. 1988. Remarks on reproductive biology of homosporous ferns. Pl. Syst. Evol., 161, 91-94.

SCHNELlER, J. J. AND HOLDEREGGER, R. 1996. Colonization events and genetic variability within populations of Asplenium ruta-muraria L. In: Camus, J. M., Gibby, M. and Johns, R. J. (eds) Pteridology in Perspective, pp. 571-580. Royal Botanic Gardens, Kew. 
SCHULZE, G. 1990. Asplenium trichomanes subsp. pachyrachis (Christ) Lovis and Reichstein, in der Pfalz. Pollichia, 77, 215-221.

SLATKIN, M. 1987. Gene flow and the geographic structure of natural populations. Science, 236, 787-792.

SOLTIS, D. E. AND SOLTIS, P. S. 1987. Polyploidy and breeding systems in homosporous Pteridophyta: a re-evaluation. Am. Nat., 130, 219-232.

SOLTIS, D. E. AND SOLTIS, P. S. 1989. Polyploidy, breeding systems, and genetic differentiation in homosporous pteridophytes. In: Soltis, D. E. and Soltis, P. S. (eds) Isozymes in Plant Biology, pp. 241-258. Dioscorides Press, Portland, OR.

SOLTIS, P.S. AND SOLTIS, D.E. 1990. Genetic variation within and among populations of ferns. Am. Fern J., 80, 161-173.

SOlTIS, D. E., HAUFLER, C. H., DARROW, D. AND GASTONY, G. 1983. Starch gel electrophoresis of ferns: a compilation of grinding buffers, gel and electrode buffers, and staining schedules. Am. Fern J., 73, 9-26.

SOlTIS, P. S., SOlTIS, D. E. AND NESS, B. D. 1989. Population genetic structure in Cheilanthes gracillima. Am. J. Bot., 76, 1114-1118.

SUTER, B. AND SCHNELlER, J. J. 1986. Autökologische Untersuchungen an der Mauerraute (Asplenium ruta-muraria L.). Farnblätter, 14, 1-14.

TRYON, R. 1970. Development and evolution of fern floras of oceanic islands. Biotropica, 2, 76-84.

TRYON, R. 1986. The biogeography of species, with special reference to ferns. Bot. Rev., 52, 117-156.

VAN ZANTEN, B. O. 1978. Experimental studies of trans-oceanic long-range dispersal of moss spores in the Southern Hemisphere. J. Hatton Bot. Lab., 44, 455-482.
VOGEL, J. C., JEßEN, S., GIBBY, M., JERMY, A. C. AND ELLIS, L. 1993. Gametophytes of Trichomanes speciosum Willd. (Hymenophyllaceae, Pteridophyta) in central Europe. Fern Gaz., 14, 227-232.

VOGEL, J. C., RUSSELl, S. J., RUMSEY, F. J., BARRETT, J. A. AND GIBBY, M. 1998a. Evidence for maternal transmission of chloroplast DNA in the genus Asplenium (Aspleniaceae, Pteridophyta). Bot. Acta, 111, 247-249.

VOGEL, J. C., RUMSEY, F. J., SCHNELlER, J. J., RUSSELL, S. J., HOLMES, J. S., BARRETT, J. A. AND GIBBY, M. 1998b. The origin, status and distribution of Asplenium presolanense stat. nov. (Aspleniaceae, Pteridophyta). Bot. Helvetica, 108, 269-288.

voGel, J. C., RUMSEY, F. J., SCHNELler, J. J., BARRETT, J. A. AND GIBBY, M. 1999. Where are the glacial refugia in Europe? Evidence from pteridophytes. Biol. J. Linn. Soc., 66, 23-37.

WATANO, Y. 1988. High levels of genetic divergence among populations in a weedy fern, Pteris multifida Poir. Pl. Sp. Biol., 3, 109-115.

WEEDEN, N. F. AND WENDEL, J. F. 1989. Genetics of plant isozymes. In: Soltis, D. E. and Soltis, P. S. (eds) Isozymes in Plant Biology, pp. 46-72. Dioscorides Press, Portland, OR.

WENDEL, J. F. AND WEEDEN, N. F. 1989. Visualisation and interpretation of plant isozymes. In: Soltis, D. E. and Soltis, P. S. (eds) Isozymes in Plant Biology, pp. 5-45. Dioscorides Press, Portland, OR.

WINDhAM, M. D. AND RABE, E. w. 1993. Cheilanthes. In: Flora of North America, vol. 2, pp. 152-169. Oxford University Press, New York. 